\title{
A review of innovations in disease and insect management and control
}

\author{
by G.A. Van Sickle ${ }^{1}$
}

Insects, diseases and fire annually cause losses equal to onethird of the allowable annual cut in British Columbia and can directly affect exports and movement of forest products. While salvage, at least partial, of the merchantable mortality has been the traditional practice, innovations in forecasting, detection and control are increasing forest management options. Examples are given of technological advances in nursery production, data analysis and interpretation using geographic information systems (GIS) and models, insect pheromones and biological controls, and quarantine requirements imposed by concerns for potential pests.

\section{Introduction}

At one time, Canada's vast forests appeared limitless. About $45 \%$ of the vast and varied land base or about 453 million ha is called forest land. However, of the 95 million ha land area comprising British Columbia, less than $30 \%$ is considered productive and economically accessible for commercial harvesting by the forest industry (Council of Forest Industries (COFI) 1989). The allocation of this land base among competing uses and the control of the forest land are under ever increasing dispute. Land use and management pressures - regionally, nationally and internationally - will continue to increase. The overall impacts of many of these pressures are as yet poorly quantified, including the growing demand for wilderness and wildlife areas, native land claims, tourism corridors, biodiversity and alternative forestry practices. Additional impacts result from losses to fires and from insects and diseases (collectively called '"pests') and there are increasing questions and concerns regarding the effects of acid rain and climate change.

The annual harvest of timber softwood and hardwoods from these Canadian forests was 177 million $\mathrm{m}^{3}$ in 1986 (COFI 1989). Fire and pests together across Canada destroyed a volume almost equal to that harvested (Van Wagner 1991). Comparable figures for British Columbia were 87 million $\mathrm{m}^{3}$ harvested, and 37 million $\mathrm{m}^{3}$ lost to pests. These estimates do not consider losses in nurseries, in aesthetic, recreation or water values, or those resulting from quarantine matters or shifts in forest management plans. From these rough estimates, it appears possible to offset some of the increased demands upon the forest volume by avoiding or reducing major losses to fire and pests and then maintain or even increase the level of timber harvest. Additionally, wise and proper management, including where appropriate the control of fire, insects and diseases in the forest, can enhance and protect the diverse values from the forest.

\footnotetext{
'Presented at the 1990 Forest Sector conference, "The Way Ahead", September 26-28, Vancouver, B.C. G.A. Van Sickle is Head of the Forest Insect and Disease Survey, Forestry Canada, 506 West Burnside Road, Victoria, B.C. V8Z 1M5.
}

Chaque année, les insectes, les maladies et les incendies provoquent des pertes équivalant au tiers de la possibilité annuelle de coupe en Colombie-Britiannique et peuvent directement affecter les exportations et la circulation de produits forestiers. Même si des coupes de récupération, du moins partielles, du volume marchand mort ont toujours été pratiquées, les innovations on matière de prévision, de détection et de lutte ont élargi les possibilités d'aménagement forestier. L'auteur présente des exemles de progrès technologiques en matière de production en pépinière, d'analyse et d'interprétation des données à l'aide de systèmes d'information géographique (SIG) et de modèles, de méthodes de lutte biologique et faisant appel à des pheromones ainsi que les exigences de quarantaine diccées par des préoccupations à l'égard d'insectes et de maladies à potentiel destructeur.

The purpose of this paper is to highlight a few recent developments and innovations in the management and control of fire, insects and diseases which can significantly affect the forest and forest management.

If you have been reading only newspapers, some innovations you will have heard of may include:

- plants that glow in the dark once they've become diseased, thus making detection much easier.

- gangs of tree-planting or tree-pruning robots guided by artificial intelligence.

- genetic engineering that has spliced genes for a natural antifreeze production into plants, protecting them when it's frosty.

- images from space pinpointing weakened or attacked trees before they are visible to observers on the ground.

While study of such techniques is underway and results may be available, perhaps even sooner than you would expect, they are still at the frontier of research and are not yet operationally applicable. The following few examples concentrate more on recent developments that are now available. Some may not be as dramatic at catching the headlines, but often some of the simpler innovations, like the wheel, can have a profound benefit.

\section{Nursery Production and Tree Improvement}

Starting in the nursery, many changes have and are taking place in seedling production including greenhouses converted to bottom heating and $\mathrm{CO}_{2}$ enrichment for improved root growth. However, the greatest transition, starting in the early 1970s, has seen production shift from largely a bare-root system to containers which now account for more than $90 \%$ of the 300 million annual production. A consequence has been a shift from largely soilborne disease problems to increased foliar mold problems. Fortunately, the most common gray mold can be greatly reduced by improving ventilation. Accordingly, simply modifying styroblocks with ventilation holes and supporting them on benches with improved air circulation from below should at least halve the losses (Peterson and Sutherland 1990).

Sirococcus blight is another nursery disease affecting shoots and causing mortality and cull of coniferous seedlings. 
The causal fungus is seed borne, but detection of infected seed lots by standard culture plating techniques was time consuming and insufficiently sensitive. In one of the first applications of monoclonal antibodies for the identification of conifer fungi, a sensitive-dot immunoassay method for detection of the fungus in spruce seed was developed (Mitchell 1988). Very small volumes of extracts from seed lots can be tested with Sirococcus strobilinus-specific monoclonal antibodies. If the spot turns gray-black, this specific fungus has been detected and the seed lot can be better managed to reduce losses through earlier detection and application of fungicides.

Not quite so simple is the progress to date to reintroduce western white pine as a valued and viable species in BC forests. The introduction of white pine blister rust in the 1920 s virtually eliminated western white pine from consideration as a management alternative, despite its excellent wood qualities and its desirability for planting in areas of root rot. While there is a need to carefully match planting stock with the geographic area of the planting site, much variability in resistance to the rust exists to be exploited and perhaps enhanced. To date, the best scions from selected and rust-tested trees suffered only $3 \%$ mortality after 25 years of outplanting, compared with 75-99\% mortality of unselected stock (Hunt and Meagher 1989). Selection of blister rust resistant clones suitable for planting in $\mathrm{BC}$ is continuing along with development of a seedling screening test (Hunt 1988). Basic research potentially applicable to other pest-host problems includes discovery of DNA variation in the host between coastal and interior forms, and a DNA sequence variation useful in distinguishing different races of the rust (White 1990). Also, the protein biochemistry of the host may be associated with rust resistance.

\section{Biological Controls and Pesticides}

In earlier years, control of forest insects was begun only after they had reached epidemic proportions and the sprays had names like DDT, Lindane, and calcium arsenate. Without question, the greatest development in this area of direct insect control has been the improvements in formulation and application of Bacillus thuringiensis (Bt). This is a naturally occurring soil bacteria which was first recognized as a natural insect pathogen in 1911. It is highly specific against defoliating insects and, if application is carefully timed, it complements rather than interferes with beneficial insects or parasites (Nealis and van Frankenhuyzen 1990; van Frankenhuyzen 1990). Usage has increased from about $1 \%$ of the total forest area sprayed across Canada in 1979 to almost $75 \%$ in 1988 . In several provinces it is the only product even considered. (There could be a problem in placing all the control eggs in one basket!) Through recombinant DNA technology, the gene coding for Bt toxin has been cloned and inserted into tobacco plants (Vaeck et al. 1987). Forestry Canada scientists are attempting a similar introduction into spruce embryo cells so that the trees will grow up with a built-in defense system, but that is still in the future and there remains a question about the insects' ability to develop a resistance to such prolonged exposure to the control agent.

Nuclear polyhedrosis viruses (NPV's) are another example of very host-specific natural pathogens that can be recovered, culturally increased, purified, and stored. They are then ready to be applied to augment and hasten the slower natural control of populations such as the Douglas-fir tussock moth before significant tree mortality and growth loss occurs. In British Columbia, the last outbreak of Douglas-fir tussock moth was in 1983 with severe defoliation over more than 23,000 ha near Kamloops. With a supply of virus already in storage, the BC Forest Service is ready for prompt action once the onset of the next infestation is detected; fortunately, a method of monitoring, detection and assessment now exists (Shepherd and Otvos 1986).

Biological control, one of the oldest methods of insect control, gained increased importance in light of the greatly increased environmental awareness of the 1980s. The success of natural enemies to regulate abundance of forest insect pests was recently reviewed (Hulme 1988). Entomopathogens such as bacteria and viruses were mentioned earlier in this paper. Predatory and parasitic insects have also been introduced against exotic insect pests which may have arrived without a complement of their natural enemies. The classical example of this is the long-term control in eastern Canada of the European spruce sawfly (Cameron 1975). More regional examples of apparent success in bringing highly damaging populations down to levels tolerable to the forest manager and general public involve larch casebearer and winter moth. Between 1966 and 1987, more than 15,000 adults of two parasites of larch casebearer were introduced and spread from sites in southeastern British Columbia. Similarly, more than 30,000 selected winter moth parasites were released between 1979 and 1981. Parasitism levels of up to $70 \%$ have been recorded at selected monitoring sites and, with the exception of some relatively short-term localized flareups, populations and damage by both of these introduced insects have been low in the latter half of the 1980s (Wood and Van Sickle 1989).

While the necessary behavioral and host range studies of European parasites potentially useful against Sitka spruce weevil are underway, a simple stopgap control measure is being field-tested. Clipping and burning of infested leaders does reduce weevil populations, but also removes the several native parasites which can reduce the weevil populations by as much as $90 \%$. Fortunately, the weevils are slightly larger than their common parasites. The good guys can be liberated and concentrated on the site by placing the carefully clipped leaders in a container screened with openings of $1.7 \mathrm{~mm}$ square (Hulme et al. 1987). Augmenting the native parasites with carefully selected introductions in low risk-rated areas, and perhaps using less susceptible host selections, should soon improve the options for managing the highly desirable Sitka spruce.

The control of vegetative, weed competition and root rots using a biological approach is presently also under study. The fungus Chondrostereum purpureum has been found to be the most effective biocontrol agent of hardwoods, significantly reducing sprouting of maple, birch and pin cherry, after application as a stump treatment (Wall 1990). The study also includes Nectria ditissima for control of red alder and Cryptodiaporthe hystrix for big leaf maple.

\section{Monitoring Systems}

Large data bases such as forest inventories and Forestry Canada's "Forest Insect and Disease Survey" have been built up over decades, but it is only with the relatively recent 
availability of database management systems and GIS Geographic Information Systems - that such masses of data can be more easily interrogated, analyzed and compared. Applications to pest management have really just begun. At the Pacific Forestry Centre, regional and provincial pest summaries are prepared, multi-year infestations are analyzed, and comparisons of pest distributions are made with biogeoclimatic zones, inventory or climatic data. Each year the results of numerous cooperative aerial surveys of insect infestations are combined to produce regional and provincial maps for information, review, control decisions and reports. Rapid integration of data from adjacent maps and combining virtually any numbers of maps or scales are easily accomplished with the developed software (Van Sickle 1989). As well, overlays of yearly defoliation maps help identify areas of greatest damage. In a similar manner, long-term records of occurrence and severity of pests can be summarized to help risk-rate stands. For example, Rhizina undulata, a root rot of newly planted seedlings, occurs periodically, but predominately in the coastal western hemlock and interior cedar hemlock biogeoclimatic zones (Callan 1990).

Another example, Douglas-fir tussock moth periodically causes severe defoliation, growth loss and mortality of young and mature Douglas-fir. Infestation records since 1916 were overlaid to determine correspondence of the insect with forest habitat and climate. Of the 12 ecological zones considered, the majority of the infestations occurred within PPBGd and IDFc and a, and within these where temperatures were moderate (1500-1900 cumulative degree days/growing season) and where moisture deficits were extreme ( -300 to $-500 \mathrm{~mm} /$ growing season) (Shepherd et al. 1989). Identification of the most susceptible areas and stand types focuses and improves monitoring techniques, provides a basis for risk assessment and identifies the probable need and frequency for direct control of infestations in future rotations. Information on the environmental requirements and limitations for outbreaks can improve predictions of where and when future outbreaks will occur, and is basic to estimating damage which may be expected with climatic shifts because of atmospheric pollution or global warming effects.

Development of a Douglas-fir tussock moth pest management system involved examination of the six infestations recorded since 1916, stand susceptibility identification through ecological associations, identification and synthesis of the insect's pheromone (the perfume the insects use to track one another; such substances are also called semiochemicals), development and calibration of a trapping system, and sequential egg mass and larval sampling techniques (Shepherd et al. 1989; Shepherd and Otvos 1986). Through annual monitoring of pheromone traps placed in selected areas of greatest outbreak frequency, trends of moth density can be determined and sampling techniques for other life stages initiated when necessary. Populations have been increasing over the past four years but should not reach infestation levels before 1991 (Wood and Van Sickle 1989).

Other pheromone-based monitoring and control systems are widely used in British Columbia. More than 7500 traps are placed throughout the province each year for detection of gypsy moth. Containment of mountain pine beetle was greatly aided by $30,000-50,000$ pheromone baits used each year since 1984 . More than $70 \mathrm{log}$ sort and mill storage yards in coastal and interior British Columbia are using multiple funnel traps, lures and trap logs to mass trap millions of ambrosia beetles and reduce lumber and log degrade. Further development and calibration of other pheromone systems continues. Efforts include systems to detect black army cutworm, to clarify and monitor taxonomic forms of our western budworms, and work with repellent and anti-aggregation chemicals.

Armillaria root disease has been a wisespread root rot problem with confusing differences in host preferences and damage over a wide geographical distribution. The picture is clearer now that scientists have recognized at least six distinct populations. With this knowledge, damage forecasts and guidelines can be more specific. Armillaria gallica in south coastal $\mathrm{BC}$, and $A$. sinapina throughout $\mathrm{BC}$, can slowly kill hardwoods but are little threat to the softwoods. Armillaria ostoyae is common to the southern half of the province, but while it can cause mortality throughout the rotation in interior stands, in coastal stands mortality usually declines after age 15 (Morrison et al. 1985). Certainly, the use of sniffing dogs, as tried in Sweden to detect annosus root rot (Swedjemark 1989), is an idea with more appeal than manually excavating root systems, but to date, only two dogs are trained and their handlers are still learning.

\section{Modeling}

Current computing capabilities have also spawned a multitude of models which endeavor to capture in mathematical expressions the many complexities of weather, growth and yield, insect and disease biologies and impacts, fire frequencies, economic and social values, etc. Through integration and simulation, short-term and long-term effects can be examined. There are massive models such as the US Douglas-fir tussock moth model and the prognosis - budworm model (Sheehan et al. 1987), but these are less appropriate and applicable to British Columbia's forests and conditions. There are, however, a wide range of computer programs and models based on data from our region which quantify the growth impact of western budworm, the spread of dwarf mistletoes, of mountain pine beetle and of root rots, the effect of spruce weevil upon height growth and log recovery, and impacts of fire on long-term AAC (Bloomberg et al. 1980; Bloomberg 1983; Reed and Errico 1986; Thomson and Alfaro 1990). The root rot and mistletoe models are being incorporated with $\mathrm{BC}$ stand growth models. The mountain pine beetle spread model has been used in support and audit of the bark beetle control project totaling $\$ 50$ million in the past 5 years. So-called expert systems to aid pest identification, and artificial intelligence decision support systems are not far behind. Already this more modern approach to transferring knowledge from research to users has been applied to the diagnosis and treatment of nutrient deficiencies (Thomson and Taylor 1990).

\section{Fire}

British Columbia's advanced fire management system, itself a significant innovation, also utilizes computing hardware and software to turn masses of historical and current data into information which can be rapidly assessed by regional staff for speedy on-the-spot decisions. Lightning strike locations are gathered in real time from 25 triangulation stations and recorded and mapped by a centralized computer 
in Victoria. Other information such as hourly weather data is gathered from automatic fire weather stations and sent by surface telemetry. Components of the Canadian Forest Fire Danger Rating System (Stocks et al. 1989) are used to synthesize the data into numerical ratings of relative fire potential including an accounting for variability in fire behavior among fuel types. Historical and current status can be visually displayed for selective geographic areas and easily compared as well as modified according to forecasted conditions (Fuglem and Grimaldi 1988). Modeling of wind and temperature data should soon provide cell-by-cell forecast capabilities of fire behavior and of smoke plume dispersal, an area of increasing public concern.

The refinement and production in the late 1970's of two different aerial igniters - the aerial ignition system and the flying drip torch - revolutionized prescribed burning and backfire ignition for wildfire suppression (Quintilio et al. 1985). The PFC/PREMO "pingpong machine" which injects capsules of potassium permanganate with ethylene glycol and ejects them from a helicopter platform has been so successful that several are in use in Australia where the concept was first considered.

\section{Plant Health and International Trade}

What is smaller than a spotted owl yet is a major factor and threat to more than $\$ 600$ million annually in wood exports from British Columbia? The pinewood nematode! It is a cylindrical worm about the size of a grain of salt; it can occur in conifers and some associated fungi and insects. Although extremely rare in British Columbia, and then only occasionally associated with previously damaged trees and pulp chips, in warmer climates such as in Japan, it has caused extensive mortality of pine. To add to the confusion, the overlap of some critical taxonomic characters creates problems in species identification, and in North America different isolates have a tail shape that ranges from mucrotype (" $M$ " form) to round-type ("R" form) (Riga et al. 1991). Scandinavian and European countries are very concerned about the potential risk of any introduction of this nematode or its most common vector, Monochamus woodborers. A requirement that all lumber exported to these countries be kiln dried is a very real possibility, although at the moment some countries are accepting certification that the lumber is free of bark or grubholes. This is an innovative form of the more familiar Plant Health phytosanitary certificate inasmuch as it is issued at the millsite by the responsible industry. Meanwhile, the taxonomy of the nematode, the susceptibility of various conifers to the nematode, and possible alternative heat treatments and schedules are being examined and developed.

\section{Conclusion}

This has been a brief look at some examples of advances in fire and pest management through the application of computers, biological knowledge, pheromones, biological controls, selection and breeding for resistance and plant health certificates. Emphasis has been on the more straightforward, operationally simple and applicable techniques available today. But, the eyes in the sky, artificial intelligence and advanced technologies are on the drawing boards and in the laboratories and could be widely available soon. By such wise and expanded applications, losses to insects, disease and fire can be reduced and the gains could compensate in part for the many other demands and withdrawals from the forest resource.

\section{References}

Bloomberg, W.J. 1983. A ground survey method for estimating loss caused by Phellinus weirii root rot. III. Simulation of disease spread and impact. Pac. For. Res. Cen. Rep. BC-R-7., 25 p. Bloomberg, W.J., R.B. Smith and A. Van Der Werld. 1980. A model of spread and intensification of dwarf mistletoe infection in young western hemlock stands. Can. J. For. Res. 10: 42-52. Callan, B.E. 1990. Rhizina root rot of conifers. For. Can. Pac. For. Cent. Pest Leaflet FPL 56. 4 p.

Cameron, J.M. 1975. Biological insecticides. Pages 25-33 In: M.L. Prebble (ed.) Aerial control of forest insects in Canada. Canadian Forestry Service, Ottawa.

Council of Forest Industries. 1989. British Columbia forest industry fact book. Vancouver, BC. 40 p.

Fuglem, P. and S. Grimaldi. 1988. British Columbia Forest Service Advanced Fire Management System. Pages 101-107 In: B.C. Lawson, B.D. Hawkes and G.N. Dalrymple, (eds.) Fire management in a climate of change. Proc. 1988 Northwest Fire Council annual meeting, November 14-15, 1988, Victoria, BC. Hulme, M.A. 1988. The recent Canadian record in applied biological control of forest insect pests. For. Chron. 64(1): 27-31. Hulme, M.A., J.W.E. Harris and A.F. Dawson. 1987. Exploiting adult girth to separate Pissodes strobi from associated insects in leaders of Picea sitchensis. Can. Entomol. 119: 751-753.

Hunt, R.S. 1988. White pine tree improvement in British Columbia. Pages 32-36 In: R.S. Hunt, Compiler. Proc. of a western white pine management symposium, Nakusp, British Columbia, 2-5 May, 1988. Canadian Forestry Service, Victoria.

Hunt, R.S. and M.D. Meagher. 1989. Incidence of blister rust on "resistant" white pine (Pinus monticola and $P$. strobus) in coastal British Columbia plantations. Can. J. Plant Pathol. 11: 419-423. Mitchell, L.A. 1988. A sensitive dot immunoassay employing monoclonal antibodies for detection of Sirococcus strobilinus in spruce seed."Plant Disease 72(8): 664-667.

Morrison, D.J., D. Chu and A.L.S. Johnson. 1985. Species of Armillaria in British Columbia. Can. J. Plant Pathol. 7: 242-246. Nealis, V. and K. van Frankenhuyzen. 1990. Interactions between Bacillus thuringiensis Berliner and Apanteles fumiferanae Vier. (Hymenoptera: Braconidae), a parasitoid of the spruce budworm, Choristoneura fumiferana (Clem.) (Lepidoptera: Tortricidae). Can. Entomol. 122(7/8): 585-594.

Peterson, M.J. and J.R. Sutherland. 1990. Controlling gray mold on container-grown Douglas-fir by modified styroblocks and underbench forced air ventilation. Western J. Appl. For. 5(3): 75-79. Quintilio, D., G. Bisgrove and T. Van Nest. 1985. Aerial igniters provide a new dimension to indirect attack. Pages 71-73 In: Proc. Intermountain Fire Council 1983 fire management workshop. Can. For. Service. Nor. For. Res. Cent. Inf. Rep. NOR-X-271.

Reed, W.J. and D. Errico. 1986. Optimal harvest scheduling at the forest-level in the presence of the risk of fire. Can. J. For. Res. 16: $266-278$.

Riga, E., J.R. Sutherland and J.M. Webster. 1991. Pathogenicity of pinewood nematode isolates and hybrids to Scots pine seedlings. Nematologica 37: 285-292.

Sheehan, K.A., N.L. Crookston, W.P. Kemp and J.J. Colbert. 1987. Modeling budworm and its host. Pages 118-136 In: Western Spruce Budworm. U.S.F.S. Tech. Bull. 1694.

Shepherd, R.F., G.A. Van Sickle and D.H.L. Clarke. 1989. Spatial relationships of Douglas-fir tussock moth defoliation within habitat and climatic zones. Pages 381-401 In: W.E. Wallner and K.A. McManus (eds.) Proc. Lymantriidae: A comparison of features of old and new world tussock moths. Sponsored jointly by Northeastern Forest Experiment Station, Broomall, PA and International Union of Forest Research Organizations. June 26-July 1, 1988. U.S.F.S. Gen. Tech. Rep. NE-123. 
Shepherd, R.F. and I.S. Otvos. 1986. Pest management of Douglas-fir tussock moth: procedures for insect monitoring, problem evaluation and control actions. For. Can. Pac. For. Cent. Inf. Rep. BC-X-270. 14 p.

Stocks, B.J., B.D. Lawson, M.E. Alexander, C.E. Van Wagner, R.S. McAlpine, T.J. Lynham and D.E. Dube. 1989. The Canadian forest fire danger rating system: an overview. For. Chron. 65(4): 258-265.

Swedjemark, G. 1989. The use of sniffing-dogs in root rot detection. Pages 180-182 In: D.J. Morrison (ed.). Proc. Seventh International Conference on Root and Butt Rots. Vernon and Victoria, British Columbia, August 9-16, 1988. IUFRO Working Party S2.06.01. Forestry Canada, Victoria, BC,

Thomson, A.J. and M.A. Taylor. 1990. An expert system for diagnosis and treatment of nutrient deficiencies of Sitka spruce in Great Britain. AI Applications 4(1): 44-52.

Thomson, A.J. and R.I. Alfaro. 1990. A method to calculate yieldcorrection factors for the overstory component of budworm-attacked Douglas-fir. For. Ecol. Manage. 31: 255-267.

Vaeck, M., A. Reynaerts, H. Hofke and S. Jansens. 1987. Transgenic plants protected from insect attack. Nature 328: 33-37. van Frankenhuyzen, K. 1990. Development and current status of Bacillus thuringiensis for control of defoliating forest insects. For. Chron. 66: 498-507.

Van Sickle, G.A. 1989. GIS - A tool in forest pest management. Pages 213-219 In: Proc. GIS 89 "A wider perspective",. March 7-10, 1989. Vancouver, B.C. FRDA Report 076. Forestry Canada, Victoria. 243 p.

Van Wagner. 1991. Forest fire statistics and the timber supply. Pages 111-118 In: D.G. Brand, (ed.). Canada's timber resources. Proc. of a national conference, Victoria, British Columbia, 3-5 June, 1990. Forestry Canada, Petawawa Nat. For. Inst., Inf. Rep. PI-X-101.

Wall, R.E. 1990. The fungus Chondrostereum purpureum as a silvicide to control stump sprouting in hardwoods. North. J. Appl. For 7(1): 17-19.

White, E.E. 1990. Chloroplast DNA in Pinus monticola 2. Survey of within-species variability of heteroplasmic individuals. Theor. Appl. Genet. 79: 251-255.

Wood, C.S. and G.A. Van Sickle. 1989. Forest insect and disease conditions, British Columbia and Yukon 1989. For. Can. Pac. For. Cen. Inf. Rep. BC-X-318. 28 p.

\section{Membership Dues 1992-1993}

\section{Active Membership}

1st and 2nd year after graduation

(grad 1992, grad 1991)*(\$2.49 G.S.T. inc.)

$\$ 86.00$

Other new members for first year $*(\$ 2.49$ G.S.T. inc.)

Married or equivalent

second member only $*(\$ 2.49$ G.S.T. inc.)

All other active members $*(\$ 2.49$ G.S.T. inc. $)$

\section{Other Memberships}

Retired members (to qualify for retired status,

member must have 15 years membership in the

Institute) $*(\$ 2.49$ G.S.T. inc. $)$

Student Members * $\$ 1.31$ G.S.T. inc.)

Sustaining Individuals (CIF/IFC Members)

Sustaining Corporate $*(\$ 4.98$ G.S.T. inc.)

Upon written application, spousal members of Active Members may have the dues of one reduced by an amount determined annually. Spousal members are members of the same Section who are living together as spouses and using the same mailing address.

The Institute year runs from July 1 to June 30. Applications dated after January 1, 1992 will be charged half dues for that Institute year. Applications dated after April 1st will be charged NO DUES for that Institute year.

Section dues are in addition and range from $\$ 5.00$ to $\$ 30.00$ per Institute year.

*Note: The portion of membership which covers the cost of the Forestry Chronicle is subject to G.S.T. For tax purposes, this cost is calculated on $\$ 38.00$ which is $\$ 2.49$ G.S.T. (except Student rate of $\$ 20.00 @ \$ 1.31$ G.S.T.) 